\title{
Jurisdiction and How States (State Bodies) Exercise Jurisdiction Under International Law
}

\author{
Arjana Llano \\ University of VIora, Ismail Qemali, Vlore, Albania \\ E-mail: ariana-llano@live.com
}

\author{
Doi:10.5901/ajis.2013.v2n9p428
}

\section{Abstract}

State jurisdiction over foreign states and citizens. The notion of jurisdiction, judicial jurisdiction, jurisdiction of international organizations, how states exercise jurisdiction: operation of intern state bodies, on behalf of which jurisdiction is exercised. Representation of states and state governments. Exercise of national jurisdiction. Criminal Jurisdiction. Jurisdiction refers to the three forms of the juridical power, which correspond to the three branches of state government: legislative, executive and judicial. Notwithstanding this definition, the term power still remains unclear, as it can refer, in the first place, to the legislative power; that is the ability to set rules on people, estates, and events (the so called prescriptive jurisdiction) in a given state. The term jurisdiction can refer even to the local public administration (government bodies) to intervene on people, estates, or events. Cases of jurisdiction absence and exclusion must be balanced with the sacrificed right and the protected interest. The methodology used. This research paper uses scientific research theoretical methods and practical methods referred to the European Court of Human Rights judgments

Keywords: State jurisdiction over foreign states and citizens - Albanian state jurisdiction over foreign states - Lack of state jurisdiction: foreign states' immunity from the jurisdiction of another state.

\section{Introduction}

The term "jurisdiction" derives from the Latin ${ }^{1}$.The term originates form the Ancient Roman Law. In the Roman law the term jurisdiction implied either the power of Praetor (Magistrate) to give justice or the power to establish juridical norms (legislative powers).

Objectively, jurisdiction is a public function implying the power of an authority to interpret and implement the norms provided by the objective law through a specifically set process.

Nowadays the term jurisdiction has different technical and legal meanings due to the various law areas of application.

The doctrine generally recognizes the term jurisdiction to mean a legal power; that is an option, or better, a competence provided by law to intervene by unilaterally establishing, modifying or extinguishing certain juridical relations based on specific procedures and principles as provided by the legal order.

In the matter of domestic jurisdiction that different states exert, there are two major concerns. The first relates to the existence or not of state authority over certain international disputes, which cannot to be settled by the concerned state. The second relates to the willingness of the state to exert the recognized state authority over such disputes.

A common expression for states' jurisdiction is that a certain state (state authority) admits to have or exert jurisdiction over individuals for certain civil or criminal actions in a given time and space. Juridical rules and principles that regulate jurisdiction are of major importance in foreign relations between states and other international bodies. This work is aimed at dealing with the way different states claim to have jurisdiction over certain issues and providing the basic rules by which jurisdiction is distributed among different states.

Apparently, the term jurisdiction means a territory where a given state exerts its authority. For instance, when a local court, in a given family case, orders that the child should not leave the court jurisdiction, the term jurisdiction here fits to the meaning of the particular state authority territory, which, in this case is the territory where the court exerts its jurisdiction.

\footnotetext{
${ }^{1}$ From the Latin Jus dicere, i.e. to speak law, to apply justice under law provisions.
} 
When certain matters enter administrative jurisdiction rather than court jurisdiction, here the term jurisdiction implies the subjective competence of various authorities within a given state.

Nowadays, the term jurisdiction is increasingly referring to the power of a given state rather than to the geographical or territorial restraints to such power, on the basis that the foundations for jurisdiction is the sovereignty of that state.

As a rule, the major claim of states to exert jurisdiction includes one or all of the following sub-claims: claim to establish orders (prescriptive jurisdiction related to certain behaviors), claim to establish rules (normative claim to allow or prohibits activities under certain provisions), claim to enforce, i.e. to implement rules (by forcing individuals through legal, physical, economical and other means), claim to punish and claim to judge various law subjects through the use of unbiased state authorities.

For analytical purposes, the author thinks that jurisdiction should be divided by criminal and civil subject. However, the civil subject is used in a broader sense and it includes either the tax area or the administrative one.

It's worth mentioning that such a division for study purposes, to some extent, diminishes the claim of certain states to exert jurisdiction outside their territory ${ }^{2}$. The European Court of Human Rights, in the case Al-Adsani, made a distinction between civil and criminal jurisdiction so as to establish if the rule of state immunity should be avoided in front of the fundamental rules of international rights of ius cogens ${ }^{3}$ order.

Under the international law, a state's jurisdictional competence is territorial competence ${ }^{4}$. As a general rule, any state can exert jurisdiction to judge on lawsuits submitted to its courts, although such lawsuits may relate to extraterritorial individuals, estates and events, within the limits provided by international law ${ }^{5}$.

The solution of any claim to exert jurisdiction should be made under common international legal recognized rules and principles. When defining the term jurisdiction, one may found an interesting perspective inside the international organization of European Council. The question whether the European Convention for the Protection of Human Rights and Fundamental Freedoms covers some actions performed outside the national territory of a given state, has been submitted even to the previous European Convention of Human Rights, which in the case of the partial occupation of Cyprus from Turkey under the French version of European Convention, concluded with the following: "The Convention Member States are due to guarantee under their jurisdiction the rights and freedoms provided by the Convention". Accordingly, such protection is to be provided for any and all individuals under the state authority and responsibility, whatever the way such authority is exercised, either inside or outside the national territories of member states ${ }^{6}$. Such conclusion has been further confirmed even by the European Court of Human Rights. This court, by its judgment in the case Loizidou vs. Turkey ${ }^{7}$, declared the Turkish state responsible for the actions performed in the area controlled by the Turkish armed forces in Cyprus, as actions in violation of the rights sanctioned by the European Convention.

The European Convention is an international multilateral treaty, and the concept of jurisdiction in this convention is similar to the concept of jurisdiction provided by the international law. As such, it should be explained under the international, interpretative and legal means and instruments.

In this area of world globalization, the issue of deterritorialization is increasingly gaining special interest and attention ${ }^{8}$, especially for the human rights law, where universality of this area is seen as a particular characteristic of the human rights ${ }^{9}$ (Ciomos,V.,2010)

With reference to the international law, jurisdiction is an unclear juridical concept full of chameleonic colorings. In the doctrine of international law, the term jurisdiction usually refers to the right of sovereign state authorities to exercise

\footnotetext{
${ }^{2}$ It commonly refers to the administrative jurisdiction, i.e. the exercise of executive power sovereign activities outside the territory of a given state.

${ }^{3}$ EctHR (GjEDNj), Al-Adsani vs. UK, The Great Hall, judgment of 21 November 2001, apl 35763/97.

${ }^{4}$ See llascu et al. Vs. Moldova and Russia, judgment of 8 June 2004 (2005) 40 EHRR.

${ }_{5}^{5}$ See case SS. Lotus, France vs. Turkey no.9, tried before the Permanent Court of International Justice (PCIJ), PCIJ Reports, Series A, no. 10, 1927, pp. 3-33.<www.icj-cij.org >

${ }^{6}$ See Application no.6780 and no.6950/75, Cyprus vs. Turkey, (1975), 2 Decisions and Reports 125, 136

${ }^{7}$ See Loizidou vs. Turkey (Merits), judgment of 18 December 1996, paragraphs 52 -7; Loizidou vs. Turkey (preliminary observations), judgment of 23 March 1995, Series A no. 310, pp.23-4, paragraph 62.

${ }^{8}$ See JANNE E. NIJMAN, New Perspectives on the Divide Between National and International Law, the contribution of C. BROLMANN, Deterritorialization in International Law: Moving Away from the Divide Between National and International Law.

${ }^{9}$ See VIRGIL CIOMOS, The Deterritorialization of Human rights, Journal for the Study of Religions and Ideologies, 9, 25 (Spring 2010): 17-27, passim
} 
legislative, executive and judicial power (adjudicative jurisdiction). The last is exercised by the state judicial authorities such as the magistrates under the judicial system organization in that state. The common denominator, however, is that the state jurisdiction is considered an attribute of states' sovereignty.

From the perspective of international law, it is very important to make a distinction between the various notions and forms of jurisdiction. For instance, this is the case of a person suspected of having committed a crime within the territory of the Republic of Albania and escaped in Turkey. Certainly the Albanian courts have the jurisdiction to try that person under the Albanian laws on guilt and innocence. However, the Albanian police (an administrative authority) have no jurisdiction to enter the Turkish state and arrest the suspect (to exert its administrative jurisdiction). In such case, the Albanian state authorities should invite the Turkish authorities (through a request of extradition ${ }^{10}$ ) to arrest and hand over the suspect, so as he might be tried in Albania.

The exercise of legislative, executive and judicial power by the competent state authorities is considered as an exercise of state jurisdiction and it is one of the major forms of the exercise of sovereignty in the territory of the relevant states. Under the rules of international law, no state can unduly and unilaterally infringe or intervene in the exercise of sovereignty of another independent state. A state (i.e. its authorities) cannon intervene in the forms and way how another state's authorities exert jurisdiction.

Affirming that the term jurisdiction has different meanings mainly related to the exercise of state power over certain individuals, estates and events, is only one aspect. Jurisdiction refers to the three forms of legal power, which correspond to the three areas of state power: legislative, executive and judicial power. Notwithstanding this definition, the term jurisdiction still remains unclear, and, in the first place, it may refer to the legislative power, that is the possibility to establish rules on individuals, estates and events (the so called prescriptive jurisdiction) in a given state (Aust, 2005, p.43). The term jurisdiction may refer even to the power of state administration (government authorities) to intervene on individuals, estates or events under certain rules so as to implement certain norms (from prescriptive jurisdiction). In this case we have to do with executive function in application of jurisdiction (the so called executive jurisdiction). To better illustrate the concept, as far as the Republic of Albania ('Albania') is concerned, an example of administrative jurisdiction is the Council of Ministers decision-making to regulate some aspects of law implementation. Another example relates to the term used in law no. 9749 of 04 May 2007, "on state police", which in section 3 of this law entitled "the police jurisdiction" provides: "The police operates in the territory of the Republic of Albania", thus implying the applicative jurisdiction of police authority.

\section{Judicial Jurisdiction}

The state jurisdictional power, i.e. the option of judicial state authorities (courts) to listen, examine and decide on particular issues related to certain individuals, estates and events by applying and implementing the law is considered as a special form of jurisdiction (judicial jurisdiction).

The judicial jurisdiction is the exercise of judicial authority through judicial procedure ending in a typical provision called final judgment. A judgment is a special powerful instrument in case no appeal remedies, under the legal system, oppose to such judgment.

The presumption, either explicit or implicit, of the judicial jurisdiction is the first step toward the initiation of a judicial procedure. As far as jurisdiction is concerned, the judicial authorities of a given state tend to revolve around two major axes: 1) extension of their jurisdiction in those areas where other states may claim to exert their jurisdiction in an extended way; 2) failure to exert jurisdiction in those areas where other states hesitate to exert their jurisdiction as they were expected to do.

Under the juridical tradition of civil law system, where Albania makes part, the Albanian judicial jurisdiction is a category broader than the courts' judicial competence. The concept of judicial jurisdiction refers to the range of cases that the Albanian courts have the power to try, if they are required to, whereas the judicial competence refers to the identification of the competent court to try a given case in the Albanian territory. The range of Albanian jurisdiction is provided by law under certain criteria related to the circumstances that involve individuals, estates or events in direct contact with the Albanian juridical order.

\footnotetext{
${ }^{10}$ Supposing that an extradition agreement exists between both states
} 


\subsection{The jurisdiction of international organizations}

In international juridical order, the term jurisdiction implies even the power of an international judicial organization (international interstate public organization) to settle, through a binding decision, a dispute aroused between states or other entities having international legal personality.

The jurisdiction of an international court (i.e. an International Organization with international legal personality) is exercised to the extent provided by the articles of incorporation.

In the international arena, usually it is the Charter to provide the jurisdiction of the organization over individuals and the kinds of disputes to be tried.

Accordingly, in order to understand the extent and manner an international entity exerts jurisdiction, one should refer to the document supporting and providing the exercise of such jurisdiction.

The jurisdiction of international judicial authorities may be a specific jurisdiction if related to disputes aroused before the international jurisdiction could provide. Furthermore, the jurisdiction of international judicial authorities may be a general jurisdiction if related to eventual disputes.

For instance, states which have recognized the jurisdiction of International Court of Justice, where Albania makes part ${ }^{11}$, assume that, for certain juridical relations related to the application of the Convention on Prevention and Punishment of the Crime of Genocide, the eventual disputes should be settled by international binding judgments of this court.

\section{How states exert jurisdiction: National authorities operating on behalf of the state exerting the jurisdiction. Representation of states and state governments.}

The domestic jurisdiction is actually exerted by the relevant state authorities. From the perspective of international law, the government represents the state almost in any kind of international relation and interaction with the international forums.

An eo nomine ${ }^{12}$ lawsuit against a government is not distinct from the lawsuit against the state of that government.

The practice of states has established an international tradition recognizing that the lawsuit against a foreign state government is identical to the lawsuit submitted against the state ${ }^{13}$. Just as the State is internationally represented by its Government, which for practical purposes identifies the State, the Government is organized in administrative subdivisions like ministries, departments, government agencies and other authorities, which function on behalf of the Government ${ }^{14}$. State authorities, ministries, departments, government agencies may be - indeed they usually are - entities with special juridical personality provided by national law ${ }^{15}$.

Although national government entities, under international law, lack the international juridical personality to act as international law bodies (sovereign states, organizations with international personality), such entities may represent the State or act on behalf of the State Government, as they are an integral part of the State ${ }^{16}$. Under national law, such government entities may be the Prime Ministry, the Ministries, the central administration authorities, the armed forces, the

\footnotetext{
11 See law no. 8489, of 19 May 1999, "withdrawal of the provision of article IX of the Convention "on Prevention and Punishment of the Crime of Genocide adopted by United Nations General Assembly of 9 December 1948" from the Republic of Albania on 12 May 1955"

12 A Latin term meaning "by that name".

${ }^{13}$ See case: The Martin Behrman, Isbrandtsen Co. v. Netherlands East Indies Government (1947) in Annual Digest, 1947, London, vol. 14, 1951, case no. 26, p. 75; case Van Heyningen v. Netherlands Indies Government, Annual Digest, 1948, London, vol. 15, 1953, case no. 43, p. 138.

${ }_{14}$ We certainly mean basic rather than procedural representation.

${ }^{15}$ As far as Albania is concerned, see article 24 of Albanian Civil Code providing: Juridical bodies (no natural bodies) may by public. Under article 25 of civil code: "juridical public bodies are state companies and institutions which operate by self-funding or state budget, and other public entities recognized by law as juridical bodies." Furthermore, law no. 9000 of 30.01 .2003 "on organization and functioning of the Council of Ministers", article 3 provides: "The Prime Ministry is a juridical public body, which supports the activity of the Council of Ministers, the Prime Minister, the deputy Prime Minister and the State Minister". As far as other Ministries are concerned, article 7 of the above-mentioned law provides: "The Ministry is a juridical, public body represented and directed by the Minister. The Ministry technically supports the activity of the minister". As far as central institutions are concerned, article 11 of the above-mentioned law provides: "The central nstitutions, which depend on the Prime Minister or the minister, are juridical public bodies established by decision of the Council of Ministers to exercise state activity in a particular area.

${ }^{16}$ Under the theory of entity representation by its body.
} 
sub-departments, the general directorates of ministries, the embassies ${ }^{17}$, the special missions ${ }^{18}$, the counselors, the special commissioners and offices, which, in a certain way respond to or are controlled by the Government.

Other independent state bodies, such as the Parliament, the national Court, etc., whose actions are identified with the actions of the state itself, are considered as actors of the state.

Other bodies and entities of any status, which operate under the national juridical order, enjoy the possibility to be defined by national law as actors on behalf of the State ${ }^{19}$.

Finally, even private entities (natural and juridical bodies) may act on behalf of the Government, and consequently of the State, once proved that they are duly authorized to act by sovereign authority under the international public law in the performance of certain actions.

Referring to the natural bodies authorized by iure imperii power, to be mentioned are heads of states (Presidents, Kings), heads of government, heads of ministerial subdivisions or departments (Ministers, especially the Minister of Foreign Affairs), ambassadors, heads of missions, diplomatic agents, special envoys etc.

Referring to the state representation by private bodies, this is the case when a given state government authorizes a juridical private body with a certain governmental (public) function related to the exercise of a sovereign authority. Accordingly, the function exercised by the juridical private body authorized by the government is considered as a sovereign state action. This is the case of certain states, which have authorized some private banks to deal with import and export licensing. In Albania we have the example of a concession given by the Albanian government to a foreign private company for the production of ID cards of Albanian citizens.

\section{State Jurisdiction: How States Exert Jurisdiction}

\subsection{The exercise of domestic jurisdiction}

Usually, a given state, under the domestic juridical order, chooses its own way of exerting jurisdiction through the relevant authorities.

When a state determines that it can exert jurisdiction over certain individuals, estates and events, such jurisdiction should be exerted within the framework of international law. Pursuant to article 2, section 7 of United Nations Chart, the state jurisdiction is somewhat autonomous; however it should not violate some principles of international law such as the protection of human rights, etc. Whether a certain case enters or not a state jurisdiction is a matter of international law. The Permanent Court of International Justice and the International Court of Justice have said their own on such issue ${ }^{20}$.

The territory is one of the major components of the state as international juridical subject. Under the recognized practice of states in the Lotus ${ }^{21}$ case, a given state has the legitimate right to exert jurisdiction within its territory, and it can exert jurisdiction outside its territory once provided by international law.

\footnotetext{
${ }^{17}$ Embassies and Consulates are peripheral bodies of Ministry of Foreign Affairs regulated by the Convention of Vienna on Diplomatic Relations of 18 April 1961, ratified by Albania by Decree no. 7164 of 10.10.1987.

${ }^{18}$ The special missions, protected by immunity, are regulated by the Convention on Special Missions. See the Convention of Vienna on the Representation of States in their relations with International Organizations of Universal Character. For more information see Law no. 9105 of 17.07.2003, "on adherence of the Republic of Albania to the "Convention on Privileges and Immunities of Specialized Agencies" and annexes", article 3, which provides: "The specialized agencies, their property and assets, wherever located and by whomsoever held, shall enjoy immunity from every form of legal process except in so far as in any particular case they have expressly waived their immunity. It is, however, understood that no waiver of immunity shall extend to any measure of execution. The premises of the specialized agencies shall be inviolable. The property and assets of the specialized agencies, wherever located and by whomsoever held, shall be immune from search, requisition, confiscation, expropriation and any other form of interference, whether by executive, administrative, judicial or legislative action".

19 This possibility of action is indicated in the case Ville de Geneve v. Consorts de civry, 1894, in Sirey, Recueil Recueil general des lois et des arrets, 1896, Paris, part 1, p. 225 et seq. and case Rousse et Maber v. Banque d'Espagne et autores, 1937, Sirey, Recueil general des lois et des arrets, 1938, Paris, part 2, p. 17 et seq. In the Uk, in the case Kahan v. Pakistan Federation, 1951, in the case Huttinger v, Upper Congo-Great African Lakes Railways Co. et al, 1934, Annual Digest, 1934, London, vol. 7, 1940, case No. 65, pp. 172- 173.

${ }^{20}$ The Permanent Court of International Justice with an advisory opinion in the case of Citizenship Decree in Tunisia and Morocco, PCIJ, Series B, no. 4, 1923, pp. 23-24. International Court of Justice, ICJ in the case of Federal Trade Commission v. Compagnie de SaintGobain-Pont-a-Mousson, ILM, 1981, pp. 597-617

${ }^{21}$ Lotus Case cit.
} 
The jurisdiction is mainly exerted on territorial basis. However, this is not the case of individuals who are inside a state's territory but outside its jurisdiction due to their immunity. There are also cases when a given state exerts its jurisdiction outside its territory. The domestic law mainly regulates the exercise or non-exercise of jurisdiction. A state is free to establish and apply its legislation within its territory.

The criminal jurisdiction of states is mainly related to the sanctioning of certain criminal offences against individuals, estates or events, which have been committed in the territory of a given state by individuals residing in the territory of that state.

The personal jurisdiction (personam), is the authority that a state court has to exercise power over an individual, independently of his country of residence. A given state may establish laws even on its citizens residing abroad (under a foreign jurisdiction), as it is the case of tax collection, or in the matter of foreign investments in that state, etc. An interesting example of the exercise of prescriptive jurisdiction outside a state's territory is the legislation in favor of free competition (antitrust) in the USA ${ }^{22}$ and the European Council.

The subject matter jurisdiction (materiae) is the authority of a court to hear cases related to a specific subject matter.

The bases of criminal jurisdiction are mainly treated in the International Public Law, whereas the civil jurisdiction is mainly dealt with in the private international law of states.

\subsection{Criminal jurisdiction}

The exercise of state authority in the territory of a given state is the most general rule of international practice. The power to judge individuals, estates and events in the territory of a state is a natural competence of the state, whose authorities determine the applicable domestic law, its application procedures and the manner of application. However, a criminal offence may be committed in two different states, and have consequences that start in one state and end in another (cross-border).

Under article 7 of Albanin Criminal Code, there is a case when the territorial jurisdiction of a state is applied even over foreign citizens. The article provides: "the foreign citizen who has committed a criminal offence in the territory of Albania is responsible under the Albanian criminal laws.

\subsection{The principle of citizenship}

The rules of citizenship in a given state are provided by the domestic law of that state ${ }^{23}$. The international law determines some important criteria on citizenship. The relation between the individual and the country he/she belongs to is one of the oldest relations ever. The possession of citizenship is associated with some rights and dues of the individual in the relevant country. Such rights and dues typically consist in the right to vote, the due to pay taxes, the due to pay military service inside the armed forces or other forces as well as the due to be loyal to your country.

At an international level, such rights consist in the right of the individual to have diplomatic protection and the due of the individual to behave in conformity with the norms provided by the domestic law.

With reference to Albania, article 6 of Albanian Criminal Code ${ }^{24}$ provides: "Albanian citizens are considered all individuals who possess another citizenship in addition to the Albanian citizenship".

\footnotetext{
${ }^{22}$ The legislation is known as Sherman Act and it is regulated by US Foreign Trade Antitrust Improvements Act 1982 (FTIA).

${ }^{23}$ Usually the law on citizenship

${ }^{24}$ Penal Code of the Republic of Albania, approved by law no. 7895 of 27.01.1995, published in Official Bulletin no. 02-1995, modified with: law no. 8175, of 23.12.1996, published in Official Bulletin no .29-1996, of 17.01.1997, p. 965; law no. 8204, of 10.04.1997, published in Official Bulletin no . 4-1997, of 17.04.1997, p. 78; law no. 8279, of 15.01.1998, published in Official Bulletin no. 1-1998, of 04.02 .1998 , p. 10, law no. 8733, of 24.01.2001, published in Official Bulletin no . 4-2001, of 26.02.2001, p. 100; law no. 9017, of 06.03.2003, published in Official Bulletin no . 21-20003,of 28.03.2003, p. 641; law no. 9030, of 13.03.2003, published in Official Bulletin no . 23-3003, of 03.04.2003, p. 729; law no. 9086, of 19.06.2003, published in Official Bulletin no . 57-2002003, of 14.07.2003, p. 2432; law no. 9188, of 12.02.2004, published in Official Bulletin no . 13-2004, of 06.03.2004, p. 541; law no. 9275, of 16.09.2004, published in Official Bulletin no .69-2004, of 07.10.2004, p. 4589; law no. 9686, of 26.02.2007, published in Official Bulletin no .27-2007, of 16.03.2007, p. 489; law no. 9859, of 21.1.2008, published in Official Bulletin no . 10-2008, of 13.02.2008, p. 301;law no. 10 023, of 27.11.2008, published in Official Bulletin no . 190-2008, of 31.12. 2008, p. 9395).
} 
A state can prosecute its citizens suspected of having committed crimes anywhere around the world (the so called principle of active jurisdiction as by the nationality (citizenship) of the suspect). Such principle is provided even by the article 17 of the Statute of International Criminal Court, which allows a state to prosecute and submit to the International Criminal Court its own citizen, who is suspected of having committed international crimes.

Such principle has been recognized by those countries, which largely apply it. In Albania, this principle is provided by article 6, section 2 of Albanian Criminal Law: "the criminal law of the Republic of Albania is applicable even to the Albanian citizen who has committed a crime in the territory of another state, when the crime is at the same time punishable and no final judgment has been given by a foreign court". In general, Albania does not oppose to the application of this principle by other states.

Some countries claim to have jurisdiction over criminal offenders based on some personal relations other than citizenship, such as the long time staying in that country etc. Countries like Albania, Italy and Brasil claim the exercise of criminal jurisdiction under the principle of passive jurisdiction. In other words, they claim jurisdiction over a foreign citizen for crimes committed outside the state's territory if that state's interests are affected. The single fact that a citizen is a victim of a foreign criminal offender cannot legitimate the state of the victim to exercise passive jurisdiction over that foreign criminal offender, unless the foreign country where the criminal offence has been committed fails to prosecute the criminal offender.

In Albania, pursuant to article 7, section 2 of the criminal code, the criminal law of the Republic of Albania is applicable even to foreign citizens, who, outside the territory of the Republic of Albania, to the detriment of Albanian and Albanian citizens' interest, commit one of the following crimes: (a) crimes against humanity; (b) crimes against independence and constitutional order; (c) terroristic actions; (d) organization of prostitution, illicit traffic of humans, children and women, production and illicit trafficking of weapons, drugs, other narcotic and psychotropic substances, nuclear substances, pornographic materials and illicit trafficking of art works and objects of certain archeological, cultural and historical value.

\section{Conclusions}

As possibilities to exercise jurisdiction extend and aim at having a greater access in justice and a more substantial justice for the concerned entity, at the same time they may present jurisdictional conflicts and tensions between states as well as some difficulties in the application of judgments given by foreign courts.

The domestic jurisdiction is actually exerted by the relevant state authorities. From the international law perspective, the State is represented by its Government in all international relations. The state authorities represent the state itself. They should be more accountable when exerting their jurisdiction, by creating a balance between the demand to access justice and other interests protected by the same principle. The bases of jurisdiction are recognized by international law.

The absence and exclusion of jurisdiction must be balanced with the right sacrificed and the interest protected.

\section{References}

Aust, A. (2005, p.43). Handbook of International Law, . London: Cambridge University Press.

V., C. ( Spring 2010). The Deterritorialization of Human rights. Journal for the Study of Religions and Ideologies , 17-27.

Penal Code of the Republic of Albania

See Janne E. Nijman, New Perspectives on the Divide Between National and International Law, the contribution of C. BROLMANN, Deterritorialization in International Law: Moving Away from the Divide Between National and International Law.

\section{Court Decision}

Application no.6780 and no.6950/75, Cyprus vs. Turkey, (1975), 2 Decisions and Reports 125, 136

SS. Lotus, France vs. Turkey no.9, tried before the Permanent Court of International Justice (PCIJ), PCIJ Reports, Series A, no. 10, 1927, pp. 3-33

In the Uk, in the case Kahan v. Pakistan Federation, 1951, in the case Huttinger v, Upper Congo-Great African Lakes Railways Co. et al, 1934, Annual Digest, 1934, London, vol. 7, 1940, case No. 65, pp. 172- 173.

Loizidou vs. Turkey (Merits), judgment of 18 December 1996, paragraphs 52 -7; Loizidou vs. Turkey (preliminary observations), judgment of 23 March 1995, Series A no. 310, pp.23-4, paragraph 62.

The Martin Behrman, Isbrandtsen Co. v. Netherlands East Indies Government (1947) in Annual 
Digest, 1947, London, vol. 14, 1951, case no. 26, p. 75; case Van Heyningen v. Netherlands Indies Government, Annual Digest, 1948, London, vol. 15, 1953, case no. 43, p. 138.

The Permanent Court of International Justice with an advisory opinion in the case of Citizenship Decree in Tunisia and Morocco, PCIJ, Series B, no. 4, 1923, pp. 23-24. International Court of Justice, ICJ in the case of Federal Trade Commission v. Compagnie de Saint-Gobain-Pont-a-Mousson, ILM, 1981, pp. 597-617

Ville de Geneve v. Consorts de civry, 1894, in Sirey, Recueil Recueil general des lois et des arrets, 1896, Paris, part 1, p. 225 et seq. and case Rousse et Maber v. Banque d'Espagne et autores, 1937, Sirey, Recueil general des lois et des arrets, 1938, Paris, part 2, p. 17 et seq. 